University of New Hampshire

University of New Hampshire Scholars' Repository

$12-1987$

\title{
Cenozoic paleoceanography 1986: An introduction
}

\author{
W. H. Berger \\ University of California - Davis \\ Larry A. Mayer \\ University of New Hampshire, larry.mayer@unh.edu
}

Follow this and additional works at: https://scholars.unh.edu/ccom_affil

Part of the Oceanography and Atmospheric Sciences and Meteorology Commons, and the Paleontology Commons

\section{Recommended Citation}

Berger, W.H., and Mayer, L.A., 1987, Cenozoic paleoceanography 1986: An introduction, in Berger, W.H. and Mayer, L.A., eds. Paleoceanography, vol. 2, no. 6, pp. 613-623

This Article is brought to you for free and open access by the Center for Coastal and Ocean Mapping at University of New Hampshire Scholars' Repository. It has been accepted for inclusion in Affiliate Scholarship by an authorized administrator of University of New Hampshire Scholars' Repository. For more information, please contact Scholarly.Communication@unh.edu. 
PALEOCEANOGRAPHY, VOL. 2, NO. 6, PAGES 613-623, DECEMBER 1987

CENOZOIC PALEOCEANOGRAPHY 1986: AN INTRODUCTION

W. H. Berger

Scripps Institution of Oceanography University of California, San Diego

La Jolla

L. A. Mayer

Department of Oceanography

Dalhousie University

Halifax, Nova Scotia, Canada

Abstract. New developments in Cenozoic paleoceanography include the application of climate models and atmospheric general circulation models to questions of climate reconstruction, the refinement of conceptual models for interpretation of the carbon isotope record in terms of carbon mass balance, paleocirculation, paleoproductivity, and the regional mapping of paleoceanographic events by acoustic stratigraphy. Sea level change emerges as a master variable to which changes in the ocean environment must be traced in many cases, and tests of the onlap-offlap paradigm therefore are of crucial importance.

\section{INTRODUCTION}

Symposia are useful in gauging the rate of advance in the particular branch of science they aim to represent, in the present case, Cenozoic Paleoceanography. Comparing the scope of topics addressed at Woods Hole, in 1986, with those addressed by earlier conferences in the field (Kiel, 1974: Riedel and Saito [1979]; Harriman, New York, 1978: Talwani et al. [1979]; Houston, 1979: Warme et al, [1981];

Copyright 1987

by the American Geophysical Union.

Paper number 7 P0882.

0883-8305/87/007P-0882\$10.00
Toronto, 1980: Berger and Crowe11 [1982]; Zürich, 1983: Hsü and Weissert [1985]), we note several new developments. Of special interest are (1) the application of climate modeling to questions bearing on the ocean heat budget; (2) the (semi)quantitative interpretation of $\delta^{13} \mathrm{C}$ signals in calcareous sediments in terms of carbon mass balance, paleocirculation, and paleoproductivity; (3) the geographic mapping of paleoceanographic events in cores and by seismic reflection profiling, and (4) the increasing appreciation of the importance of sea level as a master control variable, and of the complexities associated with its reconstruction.

Each one of these topics figured prominently in contributions to the Cenozoic Ocean Symposium 1986, both in talks and in poster sessions. Climate modeling was represented by Eric Barron (Eocene equator-to-pole surface ocean temperatures). The $\delta^{13} \mathrm{C}$ signal was the focus of studies by Michael Arthur and associates (paleoproductivity in the earliest Tertiary), by Lloyd Keigwin (climatic change in the late Miocene), by Nobuaki Niitsuma (carbon cycle changes in the late Neogene), by Fay Woodruff (Miocene deep-sea benthic foraminifera) and by Kenneth Miller and associates (Paleogene benthic foraminifera). Event stratigraphy was the subject of contributions by Gerta Keller and John Barron (Cenozoic deep-sea hiatuses), by Brian McGowran (Late Eocene events), by 


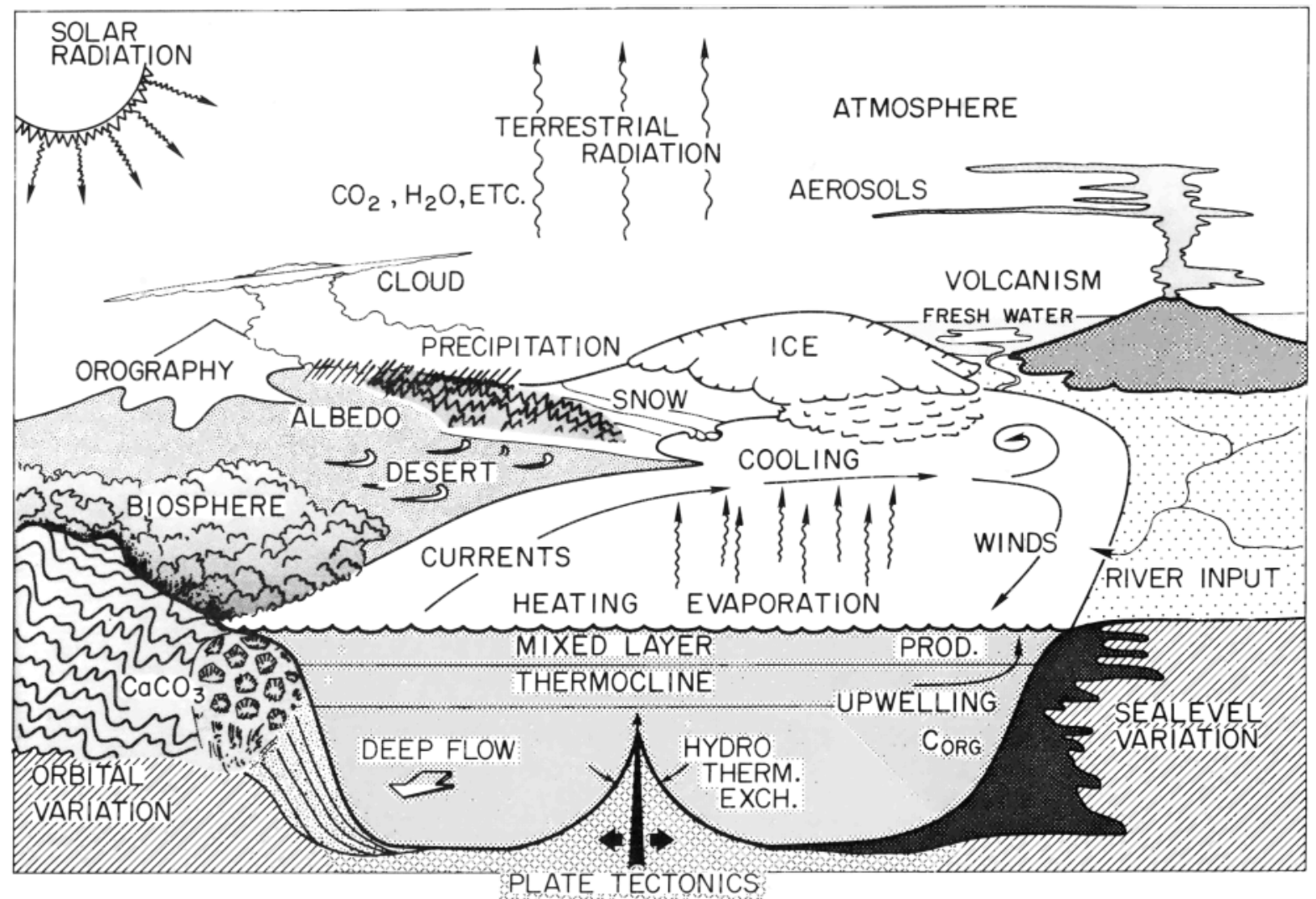

Fig. 1. Major components of the climate system, controliing ocean dynamics, and depositional patterns on the seafloor. From Berger and Labeyrie [1987], modified.

Larry Mayer (seismic stratigraphy in the equatorial Pacific), by Gregory Mountain and associates (deepwater circulation in the North Atlantic), by Daniel Muller (Messinian salinity crisis), and by Robert Thunnell and associates (Late Neogene Mediterranean connections). Sea level changes, finally, were scrutinized by Theodore Moore and associates (short-term changes in sea leve1).

A selection of these contributions appears here in this volume, as well as solicited papers from conference participants. In what follows we offer a brief introduction to the particular four topics listed. It is understood, of course, that a host of other research topics are being worked on vigorously (for example, see Kennett [1985]), not the least the traditional ones concerned with documentation of Cenozoic ocean conditions and with ever increasing stratigraphic resolution. For the latter, the ground rules are being changed rapidly, thanks to a new emphasis on high-frequency cyclicity [Arthur and Garrison, 1986].

\section{TEMPERATURE GRADIENT MODELING}

The quantitative reconstruction of paleoclimatic conditions and their physical modeling was pioneered by the CLIMAP project and associated

investigations [CLIMAP, 1976; Gates, 1976; Manabe and Hahn, 1977]. This work not only had a profound effect on paleoceanography but also on the development of modeling itself, in the new emphasis on the role of the ocean and on geological processes in the climate machine (Figure 1). Not so long ago the treatment of the ocean as a moisture source with fixed temperature distributions ("swamp ocean") was standard in general circulation models. Also, the appreciation of the complexity of geologic climatic feedback, via albedo and carbon dioxide, was quite limited.

The quantitative approach to paleoclimate is now penetrating into prePleistocene periods. In a recent study, Barron and Washington [1985] used climate modeling to explore the consequences of apparent equator-to-pole temperature 
gradients, as deduced from oxygen isotope measurements on calcareous fossils. They concluded that the proposed warm temperatures at high latitudes in the Cretaceous could not be explained with favorable geographical boundary conditions alone (such as continental positions and sea level). They postulated therefore a distinct effect from greenhouse gases. A similar conclusion was reached by Schneider et a1. [1985]. Presumably, given enough constraints on this greenhousedominated temperature residual, the actual amount of $\mathrm{CO}_{2}$ in the air could be estimated, with very interesting implications for geochemistry.

For the Woods Hole Symposium, Barron again tested the equator-to-pole temperature gradient against model predictions, this time for the Eocene. Essentially, he found that reported temperatures and the model logic are incompatible, suggesting that either geologic information has been misinterpreted, or that the model is deficient, or both.

It is possible that the problem in fact lies with the current practice of neglecting the effects of evaporationprecipitation patterns on temperature reconstruction from oxygen isotopes. If, on the whole, warm waters deliver moisture, and cold waters accept it (as is the case today), then the use of the slope of 4.2 which relates changes in $\delta^{18} 0$ to changes in temperature in the Epstein equation [Epstein et al., 1953; Emiliani, 1955] is incorrect. It is too small, and the applied value should in fact lie somewhere between 4.5 and 5 (depending on the minimum planetary temperature). The equator-to-pole temperature gradient, then, would be correspondingly increased by 10-208, presumably alleviating some of the problems with modeling the gradient. In any case, Barron's approach will lead to the sharpening of tools and arguments in both the data-gathering and the computational aspects of paleoceanographic reconstruction.

\section{THE CARBON ISOTOPE SIGNAL}

The major patterns of the carbon isotope stratigraphy of the Cenozoic ocean, that is, the range of fluctuations and the differences between planktonic and benthic foraminifera, were established together with the oxygen isotope patterns more than a decade ago [Shackleton and Kennett, 1975].' However, the interpretation of these signals in the Cenozoic could not build on a Pleistocene tradition, as for oxygen isotopes, and thus considerably lagged the availability of data.

Fluctuations in the $\delta^{13} \mathrm{C}$ of the ocean's carbon pool are now generally seen as changes in the input or output ratio of inorganic and organic carbon [Tappan, 1968; Fischer and Arthur, 1977; Scholle and Arthur, 1980], while differences between oceans are explained in terms of basin-to-basin fractionation [Vincent et al., 1980; Shackleton et al., 1983b; Keigwin and Boyle, 1985; Miller and Fairbanks, 1985]. Differences in the $\delta^{13} \mathrm{C}$ of shallow and deep water are linked to the nutrient concentration in the deep ocean, applying the arguments put forward by Broecker [1973]. A special case of the change in input/output ratio is the buildup and decay of biosphere mass, i.e., forests, which was urged by Shackleton [1977] as an explanation for transient $\delta^{13} \mathrm{C}$ changes in Pleistocene oceans.

Based on these ideas, the explanation for major $\delta^{13} \mathrm{C}$ excursions seen in the Cenozoic record is straightforward: If the benthic and the planktonic signals are parallel everywhere, the cause of fluctuations is interaction with an external reservoir. If changes are asymmetric between ocean basins, the cause is inter-ocean exchange (mainly variations in the production of North Atlantic Deep Water). If changes are different for benthics and planktonics, variations in productivity are involved.

A prominent example for the first case, that is, ocean-wide $\delta^{13} \mathrm{C}$ excursion, is centered on the Early to Middle Miocene (Figure 2). The buildup of organic carbon within the Monterey Formation and equivalent marginal marine deposits all around the Pacific appears to correlate with the carbon isotope anomaly. Under the assumptions of constant input of carbon, and of constant output of carbonate, the amount of excess organic carbon sequestered can be calculated: It is about one (present-day) ocean carbon mass, distributed over some $4 \mathrm{~m} . \mathrm{y}$. [Vincent and Berger, 1985]. If one accepts the idea that a more vigorous extraction of organic carbon should have led to a decrease in atmospheric $\mathrm{CO}_{2}$, the possibility of a chemoclimatic feedback loop emerges, whereby $\mathrm{CO}_{2}$ drawdown produces cooling and 


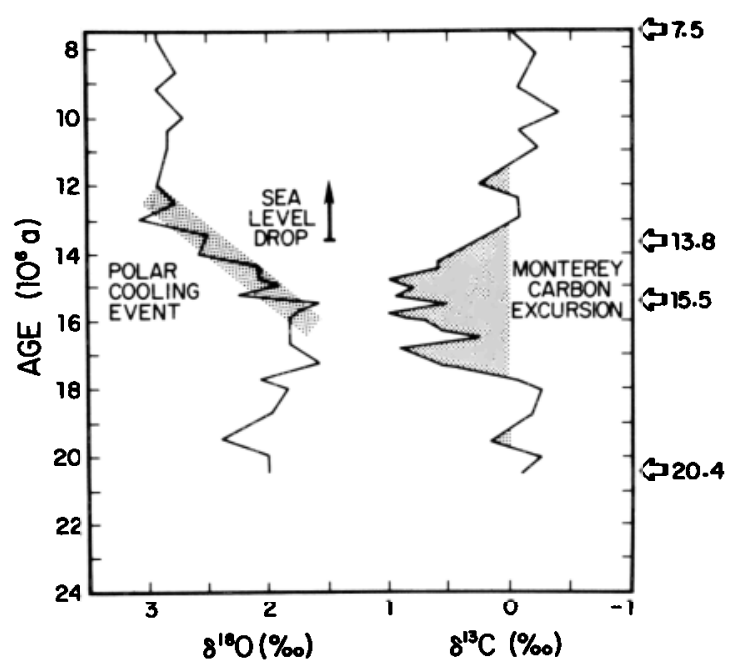

Fig. 2. Relationship between Monterey $\delta^{13} \mathrm{C}$ excursion and $\delta^{18} 0$ shift at $15 \mathrm{~m} . \mathrm{y}$., based on isotope stratigraphy in the tropical Indian Ocean (DSDP Site 216; Vincent et al. [1985]). [From Berger, 1985].

hence further upwelling and extraction of carbon.

The peculiar position of the Monterey carbon episode, with respect to the timing of bottom water cooling, is then explained as climatic preconditioning through $\mathrm{CO}_{2}$ drawdown. The rapid increase of the temperature gradient between the tropics and the region of bottom water formation, about $15 \mathrm{~m} . \mathrm{y}$. ago, suggests that a threshold was reached on a more general cooling trend. We propose that this threshold corresponds to the immigration of polar air masses into the region of potential bottom water formation. No concomitant ice buildup is necessary. If this is so, the polar front, after immigration, would have been delicately situated just beyond the Antarctic coastal zone. Thus relatively minor fluctuations in its position would have had substantial effects on deep-water formation. The data of Woodruff et al. [1981] on the isotopic composition of deep-sea benthic

foraminifera suggest that large excursions in deepwater properties did indeed occur during the early mid-Miocene cooling episode.

Development of the thinking on shallowto-deep $\delta^{13} \mathrm{C}$ differences was greatly stimulated by Broecker's [1982] model of productivity-controlled $\mathrm{pCO}_{2}$ variations. The reality of changes in the atmospheric $\mathrm{CO}_{2}$ content parallel to glacial- interglacial cycles had previously been established by the ice core studies in Bern and Grenoble [Berner et al., 1980; Delmas et al., 1980]. Broecker argued that the atmospheric $\mathrm{pCO}_{2}$, other things being equal, is a function of the efficiency with which carbon is removed from the surface waters of the ocean, whose carbon chemistry equilibrates with the atmosphere. The efficiency of extraction in turn depends on the amount of nutrients brought up by the upwelling deep water.

Relating the record of delta $\delta^{13} \mathrm{C}$ to the productivity pump has proved a useful exercise. Shackleton et al. [1983a] applied this concept to the Pleistocene record, and Shackleton [1985] also recently used it to propose a constraint on the atmospheric $\mathrm{pCO}_{2}$, in general, for the pre-Pleistocene. His argument addresses the question of how to estimate total $\mathrm{CO}_{2}$ in the ocean. Neglecting minor corrections, it may be formulated as follows: (1) the shallow-to-deep difference in $\delta{ }^{13} \mathrm{C}$ divided by 20 (the per mil deviation of the $\delta^{13} \mathrm{C}$ of marine organic matter) yields the percentage of total carbon extracted from the surface waters, relative to deep waters; (2) the maximum extraction in surface waters is given by the amount of organic carbon which can be remobilized through oxidation at depth, which is limited by the amount of oxygen available in the deep water; (3) by multipying the maximum possible extraction of organic carbon from shallow waters. with the percentage it represents (from delta $\delta^{13} \mathrm{C}$ ), one obtains the maximum amount of total ocean carbon in the ocean.

In turn, total ocean carbon yields the atmospheric carbon content under reasonable assumptions regarding ocean temperature and chemical state. Following this logic, and given the $\delta^{13} \mathrm{C}$ record, a proposal of a $\mathrm{pCO}_{2}$ of 10 times present or more [Berner et al., 1983] becomes unrealistic. Thus Shackleton's approach points the way toward direct calculation of atmospheric $\mathrm{CO}_{2}$ from the deep-sea record.

\section{EVENT STRATIGRAPHY: HIATUSES}

One result of fundamental importance which emerged from deep-sea drilling is that ocean history is punctuated by distinct events which are reflected in rather sudden changes in the facies of superposed sediments [Berggren and Ho11ister, 1977; Berger et al., 1981]. 
Commonly, these changes are accompanied by extinction and radiation, suggesting, perhaps not surprisingly, that evolution in the ocean is driven by physical changes in the ocean-atmosphere system [e.g., Benson, 1975; Wei and Kennett, 1986]. One especially interesting aspect of ocean history punctuation is hiatus formation. The presence of hiatuses interrupting the deep-sea record (a record initially probed with the expectation of finding maximum continuity) elicited surprise and vexation and proved a most intriguing and difficult problem [van Andel et al., 1975; Moore et al., 1978].

In retrospect, surprise was perhaps not called for. Geologic periods are counted present if their fossils are found. Over much of the present-day North Pacific no fossils are deposited because both carbonate and silica (such as is delivered) are dissolved on the seafloor. Furthermore, older deposits migrating down the flank of the Mid-Ocean Ridge and away from the equator are subject to chemical erosion, especially in areas where residual materials are removed, for example, by the interaction of bioturbation and gentle bottom currents. Hiatus formation, then, is widespread as a steady-state process.

There is, however, evidence for episodic hiatus formation as well, that is, for sporadic removal of previously deposited sediment, or contemporaneous removal over limited periods of time. To obtain clues, in a given case, as to type of hiatus involved (steady-state, episodic) and processes responsible (mechanical or chemical erosion, contemporaneous, or postdepositional), one must discover the exact regional and bathymetric extent of such a surface. Two methods have been used: the painstaking mapping of hiatuses based on coring results [Keller and Barron, 1983; Keller et al., 1987], and continuous seismic profiling [Mayer et al., 1986].

Core-for-core mapping of hiatuses is limited by core coverage, quality of core material, and biostratigraphic control. Nevertheless, broad patterns emerge and give rise to interesting hypotheses regarding hiatus formation. Cooling events, as seen in an increase of $\delta 0^{18}$ and in the lowering of sea level, figure prominently in recent attempts to explain hiatuses. Cooling tends to turn up the rate of formation of North Atlantic Deep Water, which would produce increased mechanical erosion in the Atlantic simultaneously with increased carbonate dissolution in the Pacific, where $\mathrm{CO}_{2}$-rich waters collect "downstream". Also, a sudden supply of soil carbon to the ocean, due to lowering of sea level and increased erosion, should result in a global carbonate dissolution event. In addition, changes in coastal upwelling intensity and basin-shelf fractionation offer mechanisms for a change in depositional patterns which should produce hiatuses in some areas and accelerate accumulation in others. Such possible explanations can be tested using the $\delta^{13} \mathrm{C}$ record, together with mass balance considerations.

\section{EVENT STRATIGRAPHY: SEISMIC PROFILING}

Acoustic stratigraphy yields continuous coverage of the sedimentary record of paleoceanographic events and is an ideal tool for interpolation between core sites. The apparent synchroneity of globally correlative oceanographic events has important implication for our understanding of the driving mechanisms of these events, and this raises the critical question of chronostratigraphic control. The correlations drawn between the seismically detected, physical, chemical, and oceanographic events described in Figure 3 are based on a "broad-brush" definition of synchroneity (equal to or less than 500,000 years difference) determined by the worst case temporal resolution afforded by the collective biostratigraphies [Mayer et al., 1986].

If we work with a single, internally consistent data set, however, and look in detail at the relationships between these parameters, we see that at a higher level of resolution the seismic, physical, and chemical events are not truly synchronous. In the region of the middle/late Miocene boundary at Deep Sea Drilling Site 575, for example (Figure 4), we clearly see a sequence of events: an isotopic excursion from relatively heavy $\delta^{18} 0$ values to relatively light ones, followed by an extreme carbonate dissolution event and then a rapid return to relatively high carbonate. The seismic horizon associated with this sequence ( $1 \mathrm{M}-\mathrm{P}$ ) is the result of the impedance contrast caused by the rapid change from high to low carbonate. Our best attempt to determine the position of these events within Exxon's "eustatic curve" framework [Haq et al., 1987] places the dissolution event within a phase of 


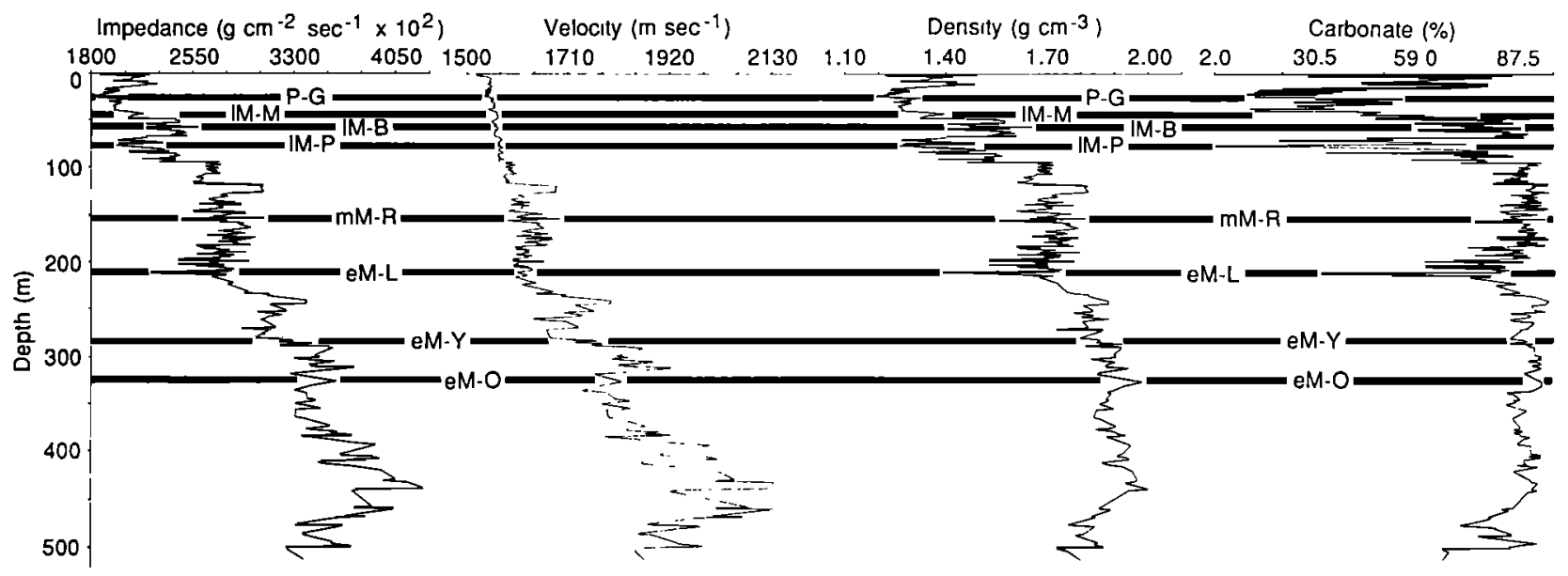

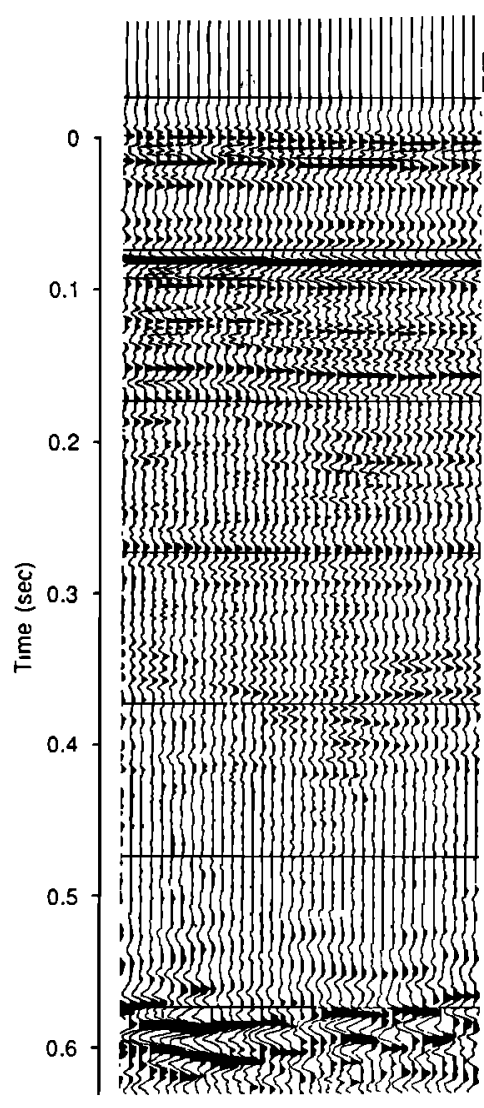

Field record

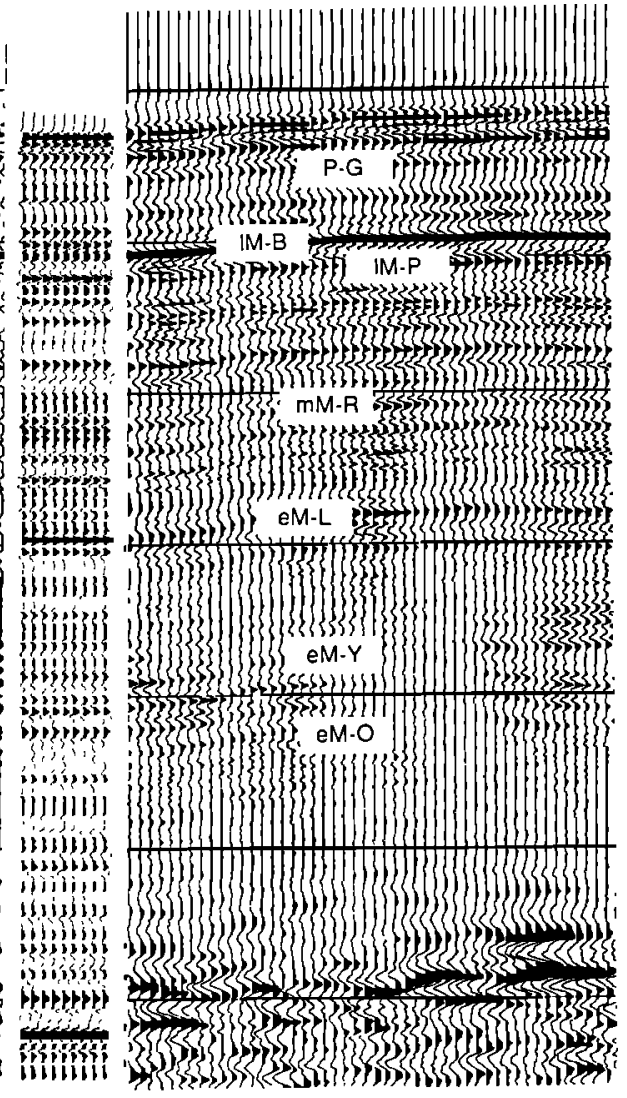

Synthelic

Field record

Fig. 3. Seismic reflectors in central equatorial Pacific sediments and interpretation [after Mayer et al., 1986]. (1) reflectors and synthetic seismograms used to determine the depth of seismic events, (2) acoustic and physical properties of DSDP Site 574 and position of reflectors, and (3) correlative oceanographic events associated with reflectors. 


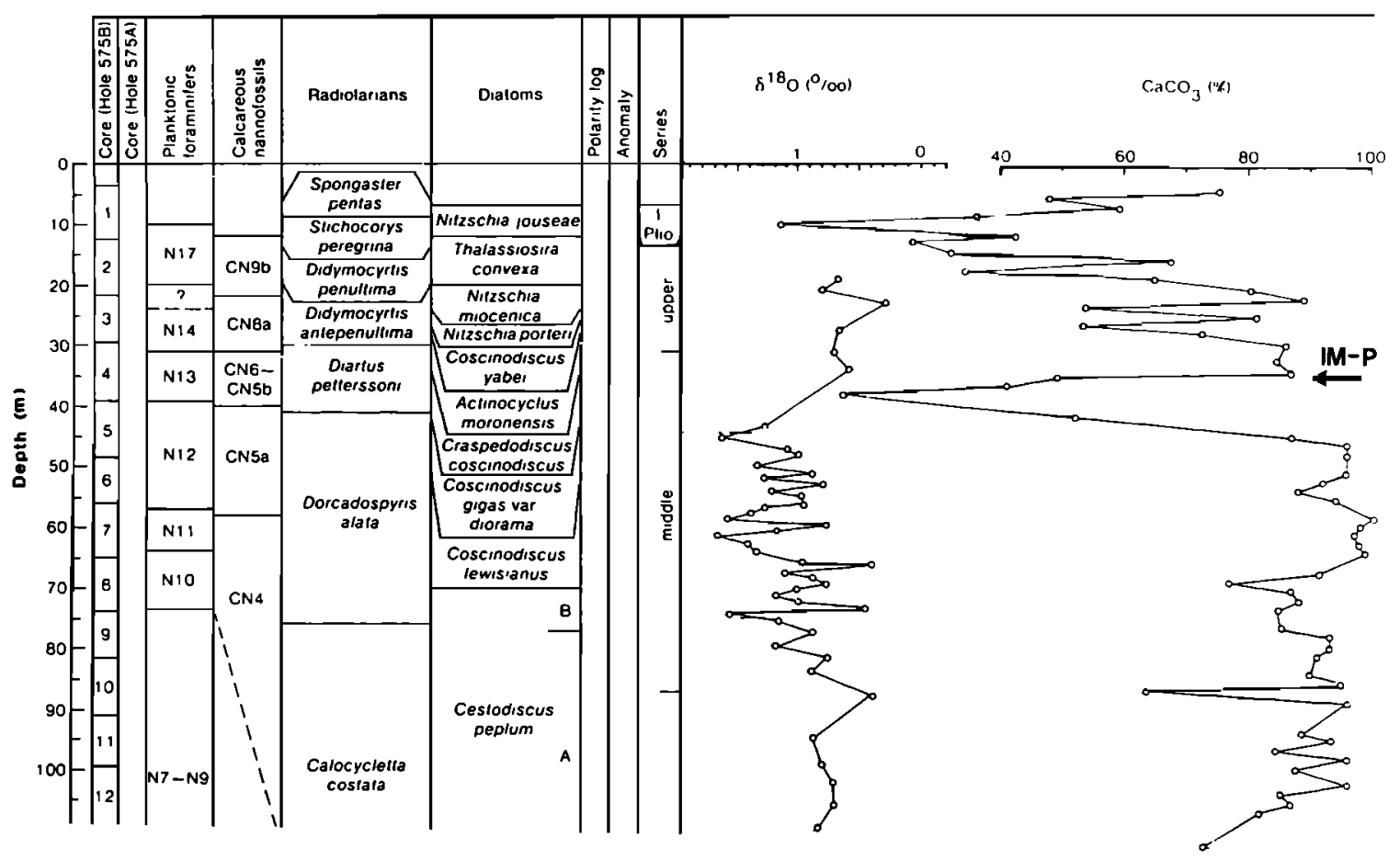

Fig. 4. Biostratigraphy, oxygen isotope, and carbonate stratigraphy of upper $100 \mathrm{~m}$ of DSDP Site 575 [after Vincent and Killingley, 1985], where 1M-P marks position of seismic horizon.

rapid sea level rise, but the precise correlation of the carbonate event with the sea level curve is not possible at this time.

A close look at the temporal relationships between the isotope, carbonate, and seismic records over this interval appears to support basin-margin fractionation as a mechanism for deep-sea hiatus formation (a shift to isotopically lighter $\delta^{18} 0$ followed closely by a dissolution event). This simple relationship, however, is by no means universal; even a quick perusal of corresponding carbonate and oxygen isotope curves at this site reveals that the ocean's response to sea level and climatic events is dominated by critical thresholds and by changes in the rate of change, which are clearly nonlinear interactions. Indeed, it is the sensitivity of the seismic signal to the facies contrasts produced by these non-linear interactions that makes seismic profiling an appealing tool for paleoceanographic investigations. One approach to unraveling the nature of oceanic response to changes in conditions is to examine the simultaneous response of different depositional regimes, i.e., basin/margin, high latitude/ low latitude, Atlantic/ Pacific, to well-documented sea level or climatic records. At present the information needed to carry out such studies is not readily available. While high-resolution seismic profiling provides the means to trace "events" over large distances, we cannot as yet draw precise stratigraphic ties from one area to the next. If event mapping is to reach its potential as a tool for addressing the fundamental problems of the oceans response to forcing, a concerted effort is necessary to generate a generalized, high-resolution marine stratigraphy.

\section{SEA LEVEL CHANGE}

There is little doubt that sea level is a master variable in Cenozoic paleoceanography, occupying a central position in the feedback system of climate, circulation, productivity, and carbonate chemistry. A change in the relative area of ocean and land directly affects the radiation balance through albedo and water vapor and heat transport mechanisms. The changing wind field in 


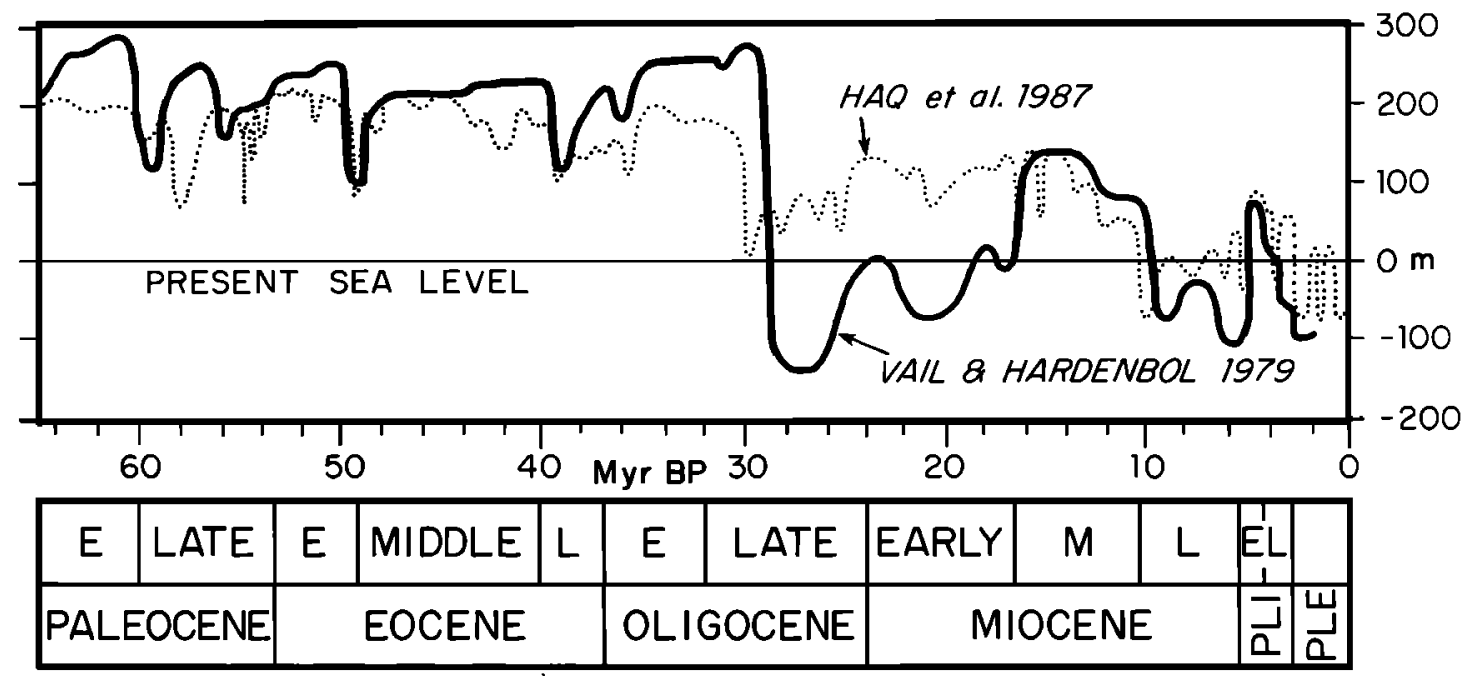

Fig. 5. Sea level variation from geometry of sediment bodies within passive margins, according to Vail and Hardenbol [1979] (solid line), based on Vail et al. [1977], and Haq et al. [1987] (dotted line).

turn affects shallow circulation, and the changing relationship between thermocline and shelf edge has consequences for the dynamics of eddy formation and upwelling. Bottom water production, of course, is tied to heat transport and evaporation patterns, which are sensitive to sea level.

The productivity of the ocean depends on the concentration of nutrients, which is, in part, a function of continental exposure (a measure of sea level), and also of the intensity of recycling, which is influenced indirectly by sea level change. The carbonate chemistry, finally, is a product of a number of factors, of which shelf-basin fractionation is the one most directly dependent on sea level.

Thus arises the intense interest of paleoceanographers in sea level reconstructions, and the instant popularity of the "Exxon sea level curve" [Vail et al., 1977] as a possible driver for the record of sedimentation rates, stable isotopes, fluctuations of the carbonate compensation depth, and hiatus abundances. The latest incarnation of this curve [Haq et al., 1987] deviates appreciably from an earlier one [Vail and Hardenbol, 1979] (see Figure 5). This suggests that there is considerable latitude in the range of possible interpretations of the basic record, that is, the geometry of sediment bodies in passive margins. Thus independent determination of sea level variation is a most urgent task. Atoll stratigraphy and geochemical arguments, e.g., Sr-isotopes, are being employed for this purpose.

Results should prove interesting and should greatly stimulate quantification of sea level effects in global ocean sedimentation models. Critical evaluation of the sea level paradigm will play a crucial part in the further development of all of paleoceanographic research.

\section{REFERENCES}

Arthur, M. A., and R. E. Garrison, Cyclicity in the Milankovitch band through geologic time: an introduction, Paleoceanography, 1, 369-372, 1986.

Barron, E. J., and W. M. Washington, Warm Cretaceous climates: high atmospheric $\mathrm{CO}_{2}$ as a plausible mechanism, in The Carbon Cycle and Atmospheric $\mathrm{CO}_{2}$ : Natural Variations Archean to Present, Geophys. Monogr. Ser., vol. 32 , edited by E. T. Sundquist and W. S. Broecker, pp. 546-553, AGU, Washington D. C., 1985.

Benson, R. H., The origin of the psychrosphere as recorded in changes of deep-sea ostracod assemblages, Lethaia, 8, 69-83, 1975.

Berger, W. H., Carbon dioxide increase and climate prediction: clues from 
deep-sea carbonates. Episodes, 8, 163$168,1985$.

Berger, W. H., and J. C. Crowell

(Eds.), Climate in Earth History,

Studies in Geophysics, 198pp. ,

National Academy Press, Washington, D. C., 1982 .

Berger, W. H., and L. D. Labeyrie, Abrupt climatic change - an introduction, in Abrupt Climatic Change - Evidence and Implications, edited by $W$. H. Berger and L. D. Labeyrie, D. Reidel, Dordrecht, Holland, pp. 3-14, 1987.

Berger, W. H., E. Vincent, and H. R. Thierstein, The deep-sea record: major steps in Cenozoic ocean evolution, Spec. Pub1. Soc Econ Paleonto1. Minera1., 32, 489-504, 1981.

Berggren, W. A., and C. D. Hollister, Plate tectonics and paleocirculation - commotion in the ocean,

Tectonophysics, 38, 11-48, 1977.

Berner, R. A., A. C. Lasaga, and R. M. Garrels, The carbonate-silicate geochemical cycle and its effect on atmospheric carbon dioxide over the past 100 million years, Am.J.Sci., 283, 641-683, 1983.

Berner, W. , H. Oeschger, and B. Stauffer, Information on the $\mathrm{CO}_{2}$ cycle from ice core studies, Radiocarbon, 22, 227-235, 1980.

Broecker, W. S., Factors controlling $\mathrm{CO}_{2}$ content in the oceans and atmosphere, AEC Symp. Ser., 30, 32-50, 1973.

Broecker, W. S., Ocean chemistry during glacial time, Geochim. Cosmochim. Acta, 46, 1689-1705, 1982.

CLIMAP Project Members, The surface of the ice-age Earth, Science, 191, 1131$1137,1976$.

Delmas, R. J., J.M. Ascencio, and M. Legrand, Polar ice evidence that atmospheric $\mathrm{CO}_{2} 20,000$ years $\mathrm{BP}$ was 508 of present, Nature, 284, 155-157, 1980 .

Emiliani, C., Pleistocene temperatures. J. Geo1., 63, 538-578, 1955 .

Epstein, S., R. Buchsbaum, H. A. Lowenstam, and H. C. Urey, Revised carbonate-water isotopic temperature scale, Geol. Soc. Am. Bu11., 64, 1315-1325, 1953.

Fischer, A. G., and M. A. Arthur, Secular variations in the pelagic realm, Spec. Pub1. Soc. Econ.

Paleonto1. Minera1., 25, 19-50, 1977.

Gates, W. L., Modeling the ice-age climate, Science, 191, 1138-1144, 1976.

Haq, B. U., J. Hardenbol, and

P. R. Vail, Chronology of fluctuating sea levels since the Triassic, Science, 235, 1156-1167, 1987.

Hsü, K. J., and H. J. Weissert (Eds.), South Atlantic paleoceanography, 350 pp., Cambridge University Press, Cambridge, 1985.

Keigwin, L. D., and E. A. Boyle, Carbon isotopes in deep-sea benthic foraminifera: precession and changes in low-latitude biomass, in The Carbon Cycle and Atmospheric $\mathrm{CO}_{2}$ : Natural Variations Archean to Present, Geophys. Monogr. Ser., vol. 32, edited by E. T. Sundquist and W. S. Broecker, pp. 319-328, AGU, Washington, D. C., 1985.

Keller, G., and J. A. Barron, Paleoceanographic implications of Miocene deep-sea hiatuses, Geol. Soc. Am. Bul1., 94, 590-613, 1983.

Keller, G., T. Herbert, B. Dorsey, S. D'Hondt, M. Johnsson, and W. R. Chi, Global distribution of Late Paleogene hiatuses, Geology, 15, $199-$ 203, 1987.

Kennett, J. P. (Ed.), The Miocene Ocean: Paleoceanography and Biogeography, Geol. Soc. Am. Mem., vol. 163, pp. 1337, Boulder, Colo., 1985.

Manabe, S., and D. G. Hahn, Simulation of the tropical climate of an ice age, $J$. Geophys. Res., 82, 3889-3911, 1977.

Mayer, L. A., T. H. Shipley, and E. L. Winterer, Equatorial Pacific seismic reflectors as indicators of global oceanographic events. Science, 233, 761-764, 1986.

Miller, K. G., and R. G. Fairbanks, Oligocene to Miocene carbon isotope cycles and abyssal circulation changes, in The Carbon Cycle and Atmospheric $\mathrm{CO}_{2}$ : Natural Variations Archean to Present, Geophys. Monogr. Ser., vol. 32, edited by

E. T. Sundquist and W. S. Broecker, pp. 469-486, AGU, Washington, D. C., 1985.

Moore, T. C., T. H. van Andel, C. Sancetta, and N. Pisias, Cenozoic hiatuses in pelagic sediments, Micropaleontology, 24, 113-138, 1978.

Riedel, W. R., and T. Saito (Eds.), Marine Plankton and Sediments. Reprints of Invited Papers, Micropaleontology Spec. Pub1., 3, American Museum of Natural History, New York, 1979. 
Schneider, S. H., S. L. Thompson, and E. J. Barron, Mid-Cretaceous continental surface temperatures: Are high $\mathrm{CO}_{2}$ concentrations needed to simulate above-freezing winter conditions?, in The Carbon Cycle and Atmospheric $\mathrm{CO}_{2}$ : Natural Variations Archean to Present, Geophys. Monogr. Ser., vol 32 , edited by

E. T. Sundquist and W. S. Broecker, pp. 554-559, 1985.

Scholle, P. A., and M. A. Arthur, Carbon isotope flucutations in Cretaceous pelagic limestones; potential stratigraphic and petroleum exploration tool, Amer. Assoc. Petr. Geol. Bul1., 64, 67-87, 1980.

Shackleton, N., Carbon-13 in Uvigerina: Tropical rainforest history and the equatorial Pacific carbonate dissolution cycles, in The Fate of Fossil Fuel CO2 in the Oceans, edited by N. R. Andersen and A. Malahoff, pp.401-427, Plenum, New York, 1977.

Shackleton, N. J., Oceanic carbon isotope constraints on oxygen and carbon dioxide in the Cenozoic atmosphere, in The Carbon Cycle and Atmospheric $\mathrm{CO}_{2}$ : Natural Variations Archean to Present, Geophys. Monogr. Ser., vol. 32, edited by E. T. Sundquist and W. S. Broecker, pp. 412-417, AGU, Washington, D. C., 1985.

Shackleton, N. J., J. Imbrie and M. Hall, Oxygen and carbon isotope record of east Pacific core V19-30: Implications for the formation of deep water in the Late Pleistocene North Atlantic, Earth Planet. Sci. Lett., 65, 233-266, 1983a.

Shackleton, N. J., M. A. Hall, J. Line, and $C$. Shuxi, Carbon isotope data in core V19-30 confirm reduced carbon dioxide concentration of the ice age atmosphere, Nature, 306, 319-322, $1983 \mathrm{~b}$.

Shackleton, N. J., and J. P. Kennett, Paleotemperature history of the Cenozoic and the initiation of Antarctic glaciation: oxygen and carbon isotope analyses in DSDP Sites 277, 279, and 281, Initial Rep. Deep Sea Dril1. Proj., 29, 743-755, 1975.

Talwani, M. , W. Hay, and W. B. F. Ryan (Eds.), Deep Drilling Results in the Atlantic Ocean: Continental Margins and Paleoenvironment, Maurice Ewing Ser., vol. 3, 437 pp, AGU, Washington, D. C., 1979.
Tappan, H., Primary production, isotopes, extinctions and the atmosphere, P.laeogeogr.

Palaeoclimato1. Palaeoecol., 4, 187 $210,1968$.

Vail, P. R., and J. Hardenbol, Sea-level changes during the Tertiary, Oceanus, $22,71-79,1979$.

Vail, P. R., R. M. Mitchum, and S. Thompson, Seisn.ico stratigraphy and global changes of sea level, Part 4: Global cycles of relative changes of sea leve1, Mem. Am. Assoc. Petr. Geol., 26, 83-87, 1977.

van Ande1, T. H., G. R. Heath, and T. C. Moore, Cenozoic History and Paleoceanography of the Central Equatorial Pacific Ocean. Geol. Soc. Am. Mem., vo1. 143, pp. 1-134, Boulder, Colo., 1975.

Vincent, E., and W. H. Berger, Carbon dioxide and polar cooling in the Miocene: the Monterey hypothesis, in The Carbon Cycle and Atmospheric $\mathrm{CO}_{2}$ : Natural Variations Archean to Present, Geophys. Monogr. Ser., vol. 32, edited by E. T. Sundquist and W. S. Broecker, pp. 455-468, AGU, Washington, D. C., 1985.

Vincent, E., and J. S. Killingley, Oxygen and carbon isotope record for the Early and Middle Miocene in the central equatorial Pacific (Leg 85) and paleoceanographic implications, Initial Rep. Deep Sea Drill. Proj., 85, 749-769, 1985.

Vincent, E., J. S. Killingley, and W. H. Berger, The Magnetic Epoch-6 Carbon Shift: A change in the ocean's ${ }^{13} \mathrm{C} /{ }^{12} \mathrm{C}$ ratio 6.2 million years ago, Mar. Micropaleontol., 5, 185-203, 1980.

Vincent, E., J. S. Killingley, and W. H. Berger, Miocene oxygen and carbon isotope stratigraphy of the tropical Indian Ocean, Mem. Geol. Soc. Am., 163, 103-130, 1985.

Warme, J. E., R. D. Douglas and E. L. Winterer (Eds.) The Deep Sea Drilling Project: A decade of progress. Soc. Econ. Paleontol. Mineral. Spec. Publ., vol. 32, 564pp, Tulsa, Okla., 1981.

Wei, K. -Y., and J. P. Kennett, Taxonomic evolution of Neogene planktonic foraminifera and paleoceanographic relations, Paleoceanography, 1, 67-84, 1986.

Woodruff, F., S. M. Savin, and R. G. Douglas, Miocene stable isotope 
record: A detailed deep Pacific Ocean study and its paleoclimatic

implications, Science, 212, 665-668, 1981.

W. H. Berger, Scripps Institution of Oceanography, University of California, San Diego, La Jolla, CA 92093.
L. A. Mayer, Department of Oceanography, Dalhousie University, Halifax, Nova Scotia, Canada B3H 4J1.

(Received November 2, 1987; revised November 10, 1987; accepted November 11, 1987.) 